\title{
Legislation on Marine Ranching in Lianyungang City and Legal Construction in Core Regions on the Intersections of the "One Belt One Road"
}

\author{
Yang Liu \\ Jiangsu College of Finance and Accounting, Lianyungang 222000, China \\ yangliu876@163.com
}

\begin{abstract}
Lianyungang City is the core area and forerunner area in promoting the construction of intersections of the "One Belt One Road" and the newly revised legislation Law gives Lianyungang City local legislative power. Legislation should go first, and therefore it is of great significance to strengthen the legislation on marine environment, especially on marine ranging for highlighting Lianyungang City as the core area and forerunner area of the construction of intersections of the "One Belt One Road".
\end{abstract}

Keywords: Marine Ranching, Legislation, One Belt One Road.

\section{连云港市海洋牧场立法暨“一带一路”交汇点核心区法治建设}

\section{杨柳}

\section{江苏财会职业学院, 连云港, 中国}

摘 要：连云港市是江苏推进 “一带一路” 交汇点建设的核心区和先导区。新修订的《立法 法》赋予了连云港市地方立法权。立法先行, 加强海洋环境立法尤其是海洋牧场立法, 对凸 显连云港市作为“一带一路”交汇点建设的核心区和先导区，具有重要意义。

关键词: 海洋牧场, 立法, 一带一路。

\section{1. 前言}

建设丝绸之路经济带和 21 世纪海上丝绸之路是习近平总书记提出的重大战略构想。连云 港市是江苏推进 “一带一路” 交汇点建设的核心区和先导区。“一带一路” 战略是连云港面 临的最大发展机遇。“一带一路” 交汇点核心区先导区建设涉及中哈物流中转基地、上合组 织出海基地以及商务、贸易、金融、保税、跨境协作、法治建设、生态保护等诸多方面。

就生态环境来说, 连云港市所属海州湾是我国海岸南北分界处, 地带过渡性的特征使其具 有十分重要的研究和保护价值。党的十八届四中全会通过的《中共中央关于全面推进依法治 国重大问题的决定》提出：“用严格的法律制度保护生态环境”。2015 年新修订的《立法法》 规定了设区的市的人民代表大会及其常务委员会有权制定地方性法规，《立法法》第七十二 条第二款规定：“设区的市的人民代表大会及其常务委员会根据本市的具体情况和实际需 要, 在不同宪法、法律、行政法规和本省、自治区的地方性法规相抵触的前提下, 可以对城 乡建设与管理、环境保护、历史文化保护等方面的事项制定地方性法规”。因此，连云港市 人民代表大会及其常务委员会可以通过制定地方性法规的形式对海洋牧场等涉及海洋环境 等问题以地方立法的形式予以保护。

本文试图借鉴国内外海洋牧场建设的经验, 从连云港市海洋牧场立法的角度对加快连云 港市 “一带一路”交汇点核心区先导区法治建设进行初步探讨。 


\section{2. 海洋牧场建设现状分析}

2.1 国外海洋牧场建设现状

2.1.1 日本海洋牧场建设情况

作为世界上最早系统研究海洋牧场的国家，日本在海洋牧场建设领域进行了大量实践，积 累了丰富的理论经验, 其海洋牧场建设总体情况居于世界领先水平。

日本海洋牧场建设重视规划体系和立法体系的保障作用, 在进行规划研究的同时, 日本政 府还建设了相关的组织机构和立法措施, 在各都、道、府县均设立海洋牧场中心、加大装备 保障力度, 在海洋牧场建设的重点海域一濑户内海单独设立了漱户内海海洋牧场中心。在制 定了沿海综合治理法的同时与之配合对日本海洋牧场协会进行了改组, 在沿海综合治理规划 中增加海洋牧场内容等。

2.1.2 韩国海洋牧场建设情况

韩国的海洋牧场建设起步时间相对较晚。20 世纪 90 年代中期, 为了恢复沿岸渔业资源, 韩国制定了《韩国海洋牧场事业的长期发展计划》，并于 1998 年正式启动实旋。

就韩国建设海洋牧场建设的实践经验而言, 按照时间任务的不同, 建设过程可主要划分 为三个阶段。第一个阶段是明确实施和管理主体, 成立专门的基金会和管理委员会, 明晰直 属管理机构和部门、研究机构以及具体实施负责机构等；第二个阶段主要是海洋牧场建设 的关键实施环节, 主要包括人工繁育目标苗种并放流到目的海区：第三阶段则是后期维护运 营、长期监督管理和资源恢复效果的分析评估。从海洋牧场建设的科学性而言, 韩国的实践 案例对韩国其他海区乃至我国的海洋牧场建设都有极大的参考价值。从海洋牧场建设的技术 角度看, 韩国在建设的各个环节方面都投入了较多地科研精力, 有效地保障了海洋牧场的运 行效果，值得参考借鉴。

2.2 国外海洋牧场建设的经验借鉴

(一) 要做长久规划, 成立海洋牧场管理与运营部门

日本从 70 年代开始提出建设海洋牧场, 但经过二三十年的发展, 才建成严格意义上的海 洋牧场。韩国在 1994-1996 年进行了海洋牧场建设的可行性研究, 并对海洋牧场的建设做了 从 1998--2030 年的长期规划。当前中国又将海洋经济作为发展重点, 各地应该从实际情况出 发, 进行海洋牧场建设可行性研究, 并做好长期建设规划。韩国成立了专门负责海洋牧场建 设和实施的部门一海洋牧场管理和发展中心，具体负责管理监督、项目协调、绩效考评等作 用。

（二）充分调动渔民、企业、社会团体积极性

日本、韩国在海洋牧场建设过程中，渔民、社会团体和企业都积极参与投资，在有关当 局批准下, 有钱出钱, 有物出物, 并采用谁投资, 谁受益, 谁管理的方式。海洋牧场的建设 应该在政府主导下，引进更多人员和资金的投入，以加快海洋牧场的建设。

\section{（三）良好的政府支持体系}

政府应该通过多种途径引导和支持海洋牧场的建设。日本和韩国将海洋牧场建设列入国 家规划, 从国家宏观政策上支持了海洋牧场的建设。同时, 各级地方也积极出台相关法规政 策，引导和支持海洋牧场的建设，充分调动渔民、企业、社会团体的积极性。

2.3 国内海洋牧场建设现状

海洋牧场作为一种环境友好型海洋渔业生产方式, 有机结合了海洋养殖业和海洋捕捞业的 优点, 代表了海洋渔业未来的发展方向。我国自上世纪七十年代开始了海洋牧场建设的探 索和实践。

\subsection{1 山东省海洋牧场建设情况}

山东省海洋牧场建设初期, 对海洋牧场的认知和理解停留在人工增殖放流与人工鱼礁投放 相结合的初级阶段, 因此其海洋牧场建设重点也集中在人工鱼礁群建设上。自 2005 年实施“山 东省渔业资源修复计划” 以来, 取得了较好的生态效益和经济效益, 也为山东省海洋牧场建 设打下了良好的基础。 


\section{3.2 辽宁省海洋牧场建设情况}

辽宁省海洋牧场建设走的是龙头企业带动、政府辅助推动的路子。辽宁省内以獐子岛集团 为代表的大型海洋渔业公司已经建成为我国目前最大的海洋牧场。但獐子岛集体企业的运作 模式在其快速发展中己逐步暴露出企业运作不够透明、渔民收入较低制约了劳动积极性的发 挥等问题, 不但影响了其海洋牧场的后续建设, 也使其成功经验的推广价值较低, 不利于大 范围推广普及。

\subsection{3 浙江省海洋牧场建设情况}

浙江省是我国传统海洋渔业大省, 其海洋牧场建设是在环境恶化、渔业产业发展转型升级 压力巨大的前提下, 主动转型发展起来的。浙江省充分挖掘海洋牧场在生态养殖方面的优势, 改变以往单纯的 “捞海” 的渔业生产方式，向 “耕海”、“养海” 的渔业生产方式转型升级。 宁波市在进行一系列海洋牧场建设的同时, 还为海洋牧场建设出台相关法律法规, 强调规划 引领作用, 先后出台了一系列资源环境保护和管理条例, 并设立了非山列岛海洋生态自然保 护区和渔山列岛海洋特别保护区。

\section{3. 连云港市海洋牧场存在问题及建议}

连云港市海岸线总长 211.6 千米。海岸类型齐全, 海岸线绵延曲折, 有江苏唯一的基岩港 湾海岸 40 千米和仅有的砂质海岸 30 千米。领海基线以内海域面积约 6677 平方千米, 沿海滩 涂 10.7 万公顷, 可开发浅海水域 26.7 万公顷。全市有海岛 20 个, 其中江苏省 9 个较大基岩 海岛均在连云港市, 是江苏省的黄金海岸。

就生态环境来说, 海州湾是我国海岸南北分界处, 地带过渡性的特征使其具有十分重要的 研究和保护价值。海州湾渔场是我国传统八大渔场之一, 有 150 余种浮游生物、200 多种鱼 类、100 余种软体动物、30 种虾类和 38 种蟹类, 名贵品种有大黄鱼、小黄鱼、鲈鱼、黑鲖、 真鲷、中国对虾、海参、鲍鱼、扇贝等, 是江苏省唯一的海珍品自然分布区。但是由于多年 来过度捕捞、环境污染等原因, 导致海州湾出现渔业资源衰退、海洋环境质量下降的迹象。 上世纪末，本地传统的经济鱼种大黄鱼、小黄鱼、乌贼等已无法形成渔汛，沿海渔民面临着 无鱼可捕的困境。

以往那种单纯追求渔业产量的时代已经过去, 取而代之的是渔业资源修复保护、水生动物 增殖和高效集约化渔业生产水平的提高 。连云港市于 2002 年启动海洋牧场相关工作, 经过 广泛科学的论证, 确定将海洋牧场建设作为恢复海州湾渔业资源和生态环境的最佳选择。 2003 年, 借助国家海洋捕捞渔民转产转业政策, 连云港市在省内率先开展海洋牧场建设。经 过 10 多年的建设, 累计投入 8000 余万元, 投放各类人工鱼礁达 6.6 万个, 总规模超 20 万空 方, 形成海洋牧场面积 160 平方公里。连云港市海洋牧场建设产生了巨大的经济、社会和生 态效益。海洋牧场区域环境状况有明显改善, 海洋牧场区域海洋生物的种类和资源量明显增 加。2015 年 11 月, 农业部批准海州湾海洋牧场示范区为全国首批 20 个国家级海洋牧场示范 区之一。

\section{1 连云港市海洋牧场建设存在的问题}

连云港市在海洋牧场的建设过程中, 在取得良好效益的同时也面临着一些突出的矛盾和问 题。根据国务院《关于促进海洋渔业持续健康发展的若干意见》和《关于印发全国海洋主体 功能区规划的通知》中对海洋牧场的建设要求, 迫切需要以立法形式明确海洋牧场管理相关 事项。

\section{(一) 缺乏专门规划。}

虽然国务院《关于印发全国海洋主体功能区规划》（国发〔2015〕42 号）中提出了 “以海 州湾、苏北浅滩为重点, 扩大海洋牧场规模, 发展工厂化、集约化生态养殖” , 国务院批准 的《江苏省海洋功能区划（2011－2020 年）》对连云港市海洋牧场也进行了布局, 但是连云 港市级层面缺乏专门的海洋牧场规划, 海洋牧场建设还不能连云港市渔业发展、海洋环境保 
护、港口建设、航道建设、海岛保护等进行有效衔接。由于缺乏规划, 严重制约了连云港市 海洋牧场的发展。

（二）融资渠道不健全。

海洋牧场建设是一项公益事业，除了国家资金投入以外，还需要地方有配套资金投入，同 时也要鼓励社会企业和个人参与人工鱼礁建设的投资，以形成多元化的投资机制。但是，连 云港市海洋牧场的建设全部是中央财政资金投入, 江苏省和连云港市财政均未安排过专项资 金，也没有引入社会资本参与开发。

(三)管理体制滞后。

连云港市海洋与渔业主管部门既作为建设主体又是行业主管部门, 现行的建设-管理模式 将严重制约其建设水平和规模。对 “谁来建设、怎样建设海洋牧场” 没有明确规定和规范性 标准, 导致海洋牧场的建设审批流程、投资强度、生产经营方式等缺乏管理、指导依据, 无 法实现有序管理。海洋牧场建成后, 没有设置专门的职能部门进行监督管理, 仅仅依靠连云 港市海洋与渔业主管部门无法实现有效管理。

（四）执法缺乏依据。

海洋生物栖息场所的污染和破坏是海州湾渔业资源可持续发展的主要威胁, 破坏礁体等事 件也时有发生。由于缺少海洋牧场管理专项法律法规, 执法部门只能对海洋牧场区内出现的 违规捕捞、非法养殖行为进行处罚, 而对于在海洋牧场区域内破坏礁体、无序生产等严重影 响海洋牧场建设和破坏生态环境的行为却不能予以处置, 无法实行有效监管。

（五）审批手续繁琐。

目前, 我国对海洋牧场建设缺乏完善的审批制度, 实践中主要依托海域审批制度进行操作。 现行海域审批制度除了因为缺乏海域流转相关法律法规导致流转不便以外, 还存在将海洋牧 场建设用海与筏式养殖、底播养殖用海区别对待, 变更用海登记手续繁琐等问题, 不利于海 域整合使用、集约开发, 制约了海洋牧场在近、浅海的大规模建设。

(六) 深度开发不足。连云港市开展海洋牧场建设以来, 沿海渔民仍是以养殖、捕捞等传统 渔业生产方式为主, 尚未形成新的业态, 如海上观光、潜水采捕等。海洋牧场的产业链延伸 不足, 经济、社会效益未得到深度开发。

为了落实国务院《关于促进海洋渔业持续健康发展的若干意见》和《关于印发全国海洋主 体功能区规划的通知》中对海洋牧场的建设要求, 提高海洋牧场的开发和管理水平, 充分发 挥海洋牧场的效益, 迫切需要以立法形式明确海洋牧场管理相关事项。

\section{2 关于连云港市海洋牧场立法的建议}

近年来, 保护海洋、开发海洋的公众意识逐渐增强, 社会各阶层都意识到了海洋战略的重 要意义。我们应当以严谨细致的工作，做好连云港市海洋牧场的地方立法工作。

(一) 加强海洋牧场规划。

依据国务院《关于印发全国海洋主体功能区规划》和国务院批准的《江苏省海洋功能区划 （2011－2020 年）》对连云港市海洋牧场的布局, 在立法中对连云港市海洋牧场规划作出专 门安排, 使连云港市海洋牧场建设与连云港市渔业养殖规划、海洋环境保护规划、港口规划、 航道规划、海岛规划防洪规划、旅游规划、工业规划、城市发展规划等进行有效衔接。

（二）完善海洋牧场投融资体系。

安排财政专项资金用于扶持海洋牧场建设，对海洋牧场建设项目给予宽松的信贷条件。 海洋牧场建设资金需求巨大，除了上级财政资金投入外，应当在立法中明确连云港市级财政 和相关区县财政每年应当安排专项资金, 设立 “海洋牧场建设建设专项资金”。同时, 要鼓 励社会资本投入到海洋牧场建设中, 可以吸引海内外财团、企业、个人等社会资金的投入, 以形成连云港市海洋牧场开发和建设的多元化投资机制。并且, 还需要有优惠的税收政策、 财政扶持政策以及保护投资者利益的规定。 


\section{(三) 完善管理体制。}

将建设主体和监督主体分开来, 做到分工明确, 职责法定。在海洋牧场的建设过程中, 海 洋与渔业部门承担监督管理职责, 海洋牧场本身的开发、建设和日常运行由专门的主体来负 责, 实现建管分离, 规范海洋牧场建设和管理。建设主体既可以是开发管理委员会, 也可以 是事业单位或国有企业, 还可以是社会投资主体, 负责海洋牧场开发、建设和运行管理工作。 通过借鉴国内外海洋牧场建设的有益经验, 为推动连云港市海洋牧场事业的发展, 建议设立 专门的海洋牧场管委会, 专门负责海洋牧场的开发、建设和运行管理工作。

（四）坚持 “生态优先” 原则。

海洋牧场的建设和发展和良好的海洋生态环境息息相关, 建议在立法中本着 “生态优先” 的原则, 将海洋生态环境的保护贯穿于海洋牧场规划、建设、经营和管理等各个环节。通过 制定条例, 明确各部门的生态保护管理权责, 确保各项管理工作推进有力、执行到位; 避免 过去执法无据的情况, 为执法机构加强海洋牧场执法提供法律依据, 有利于依法打击损害海 洋生态环境的违法行为。在法律责任一章, 根据破坏海洋牧场生态环境行为的情节, 规定依 法应当承担民事、行政、刑事责任的情形。

（五）简化审批手续。

在地方立法中, 海洋牧场审批主要涉及到海洋牧场规划审批, 海域使用权的取得的审批及 项目建成后的验收等。要按照 “简政放权, 放管结合, 加强服务” 的要求, 尽可能减少审批 事项, 压缩审批环节, 简化审批程序。要减少前置审批, 加强事中事后监督, 为海洋牧场领 域的大众创业、万众创新创造便利条件。

（六）建立海洋牧场的物权保护制度。

在立法上让海洋牧场的投资方享有对海洋牧场建设中有关资产的所有权、用益物权和担保 物权, 以立法的形式界定和保护海洋牧场建设投资方的权益, 避免海洋牧场建设中的短期行 为给投资方利益造成的损害。要建立和实施海洋牧场的物权化管理, 使从业者共同参与海洋 牧场的管理, 为海洋牧场的建设、维护建立立法保障。在立法中可以规定海洋牧场流转的有 关规定, 为海洋牧场的转让、抵押等提供法律依据。

本文围绕加快连云港市 “一带一路” 交汇点核心区先导区法治建设, 在借鉴国内外海洋牧 场立法经验做法的基础上, 对加强连云港市海洋牧场立法建设进行了探讨。文章分析了我国 海洋牧场立法存在缺乏专门规划, 融资渠道不健全, 管理体制滞后, 执法缺乏依据, 审批手 续繁琐, 深度开发不足等问题, 提出了海洋牧场立法应当加强海洋牧场规划, 坚持 “生态优 先” 原则, 简化审批手续; 在完善海洋牧场投融资体系方面, 建议在立法上确立连云港市海 洋牧场开发和建设的多元化投资机制; 在完善管理体制方面, 建议在立法上将建设主体和监 督主体分开, 做到分工明确, 职责法定; 在建立海洋牧场的物权保护制度方面, 建议在立法 上让海洋牧场的投资方享有对海洋牧场建设中有关资产的所有权、用益物权和担保物权。

\section{References}

[1] Yuanan Yu, The Development Situation of Marine Ranching in South Korea and Japan and An Analysis on Necessity of Carrying out this Project in China [J], China Fishery, 2008, 03

[2] Bo Li, On the Construction of Marine Ranching in China [D].China Ocean University, 2012

[3] Chinese Academy of Fishery Sciences, A research on Development Strategies for Key Areas in China's Fisheries Science and Technology in early 21st Century [M], Beijing Agricultural Science and Technology Press, 1999,26

[4] Zhennuan Qi, Exploration and Practice of the Construction of Public Welfare Artificial Reef in Laoshan Bay, Qingdao [J], Fisheries Information and Strategy, 2014,02

[5] Enchen Wang, On Construction and Upgrading of Marine Ranging [D], China Ocean University, 2015 